\title{
CHANGES IN LAND USE AND VEGETATION IN CACHEU RIVER MANGROVES NATURAL PARK, GUINEA-BISSAU: CONTRIBUTION TO SUSTAINABLE MANAGEMENT OF THE PARK.
}

\author{
María Isabel Más-López ${ }^{1}$, and Eva M. García del Toro ${ }^{2, *}$ \\ 1 Departamento: Ingeniería Civil: Construcción Infraestructura y transporte; mariaisabel.mas@upm.es \\ 2 Departo Ingeniería Civil: Hidráulica y Ordenación del Territorio; evamaria.garcia@upm.es \\ * Correspondence: Eva M. García del Toro.
}

\begin{abstract}
The aim of this paper is to study changes in land use and the evolution of vegetation in Cacheu River Mangroves Natural Park in the Republic of Guinea-Bissau. To do this, we will study variations in the NDVI, Normalized Difference Vegetation Index. In order to perform the calculations and subsequent analysis, images from three years - 2010, and 2017-were used, all corresponding to the same time of year so that the phenological stage is the same. To perform a more reliable analysis, the park was divided into five classes based on the main use of the land: mangals, palm forest, paddy fields, savannahs and others. Using a statistical sample, same areas were selected for each class and the corresponding NDVIs were calculated for the years in which ASTER images were available. The study made it possible to conclude that at present, management of the park is not the most suitable, given that the changes in land use observed represent a decrease in mangrove swamps, despite the fact that these forests constitute the most important ecological area of all those that make up the park. Mangals are being replaced by other land uses.
\end{abstract}

Keywords: Mangals, Sustainability, Vegetation Indices, Land Use, Environmental Management.

\section{Introduction}

Around the world, one hundred and sixty-three countries and territories with a total forest area of 3.7 billion ha recently reported that about 2.2 billion ha are intended to be kept under permanent forest land use [1] Of these, close to 1 billion ha are found in the tropic [2] The rich biodiversity of these areas and the many roles they play in the functioning of the Earth system at local regional and global scales are the reason behind this maintenance effort[3] Of the world's major tropical forest regions, most research and policy attention has focused on the Amazon region; whereas, the tropical forests of Central and West Africa, which constitute world's second largest tropical forest region, have been relatively neglected.[4] Guinea-Bissau is one of these countries, where the sustainability of protected areas,[5] of utmost importance from the economic and environmental perspective. Conservation of these areas with their full array of species, viable populations, and ecosystems depends on the effective protection, management, and expansion of its rain forest parks[6].

The area of study is located in northwest Guinea-Bissau, between $12^{\mathrm{o}} 10^{\prime}-12^{\mathrm{o}} 25^{\prime} \mathrm{N}$ and $15^{\mathrm{o}} 55^{\prime}-$ $16^{\circ} 27^{\prime} \mathrm{W}$. Its location is shown in Figures 1 and 2. 


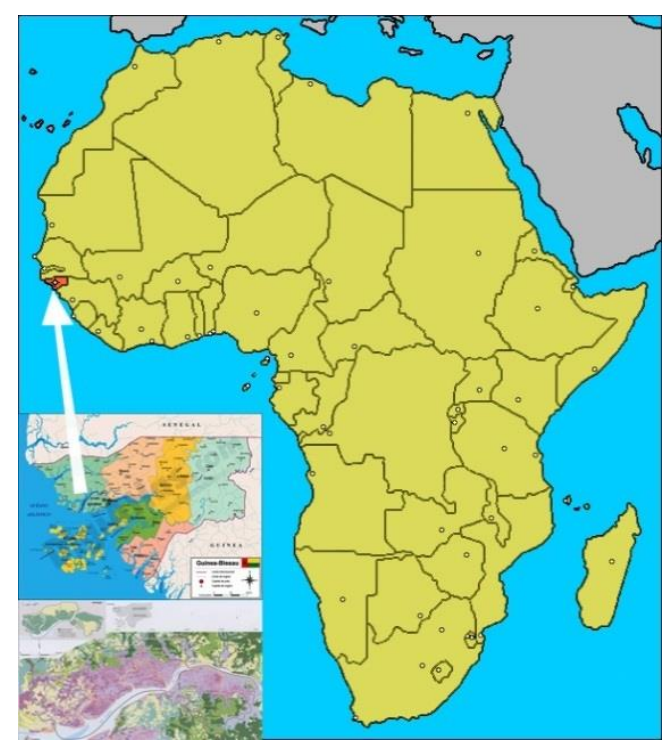

Figure 1: General map of the location of Guinea-Bissau and Cacheu River Mangroves Natural Park

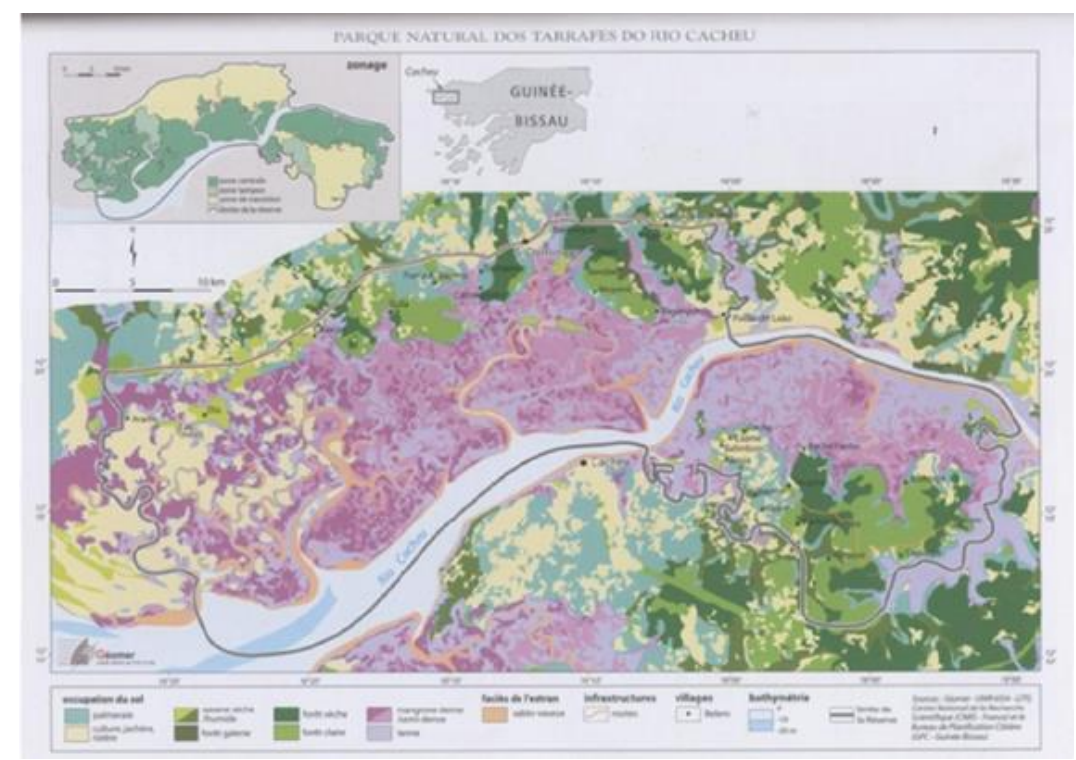

Figure 2: Location map of Cacheu River Mangroves Natural Park. Source: WDPA

The park's total vegetation extends across an 88,615 ha area, $68 \%$ of which is covered by mangals. Mangals are assemblages of woody plants known as mangroves. [7] These shrubs or small trees grow at the interface between land and sea in tropical and sub-tropical latitudes where they exist in conditions of high salinity (halophytes), and harsh coastal conditions such as extreme tides, strong winds, and high temperatures[8] (They are also adapted to the low oxygen conditions of waterlogged mud [9].

In addition to mangals, the park also contains large areas of palm forest, savannah and paddy fields, mixed with small population centers.

From an ecological perspective, mangrove forests are extraordinarily important[10][11] for several reasons: 
- They form a protective barrier against tsunamis and tidal waves,[12][13] due to the stability created by the complex framework of roots. In addition, the aerial part, made up of stems and branches that form a tall, dense canopy, is a natural barrier against wind erosion and protection against hurricane-force winds.

- The roots of the tree and shrub species function like a green filter, neutralizing pollutants such as heavy metals and toxic compounds.[14]They therefore purify the waters of rivers and effluents from surrounding settlements and small industries.

- They are mating and breeding areas and the habitat for the juvenile stages of many coastal pelagic fish, mollusks, crustaceans, echinoderms and annelids, whose habitats in the adult stages are areas of phanerogams, marshes, coastal lagoons and inland fresh water [15]. Approximately $70 \%$ of the organisms captured at sea carry out part of their life cycle in a mangrove swamp or coastal lagoon.[16] The great variety of species to which the mangals are home make up a complicated trophic network, maintaining a large number of reptile and bird species, some of which are endangered.

- They are important carbon sinks and produce large amounts of oxygen, which they return to the atmosphere.[17].

- They regulate the flow of rainwater and reduce the effects of flooding. [12].

- They are a palliative against climate change, as they are $\mathrm{CO}_{2}$ fixers and also because of the redox reactions they carry out on nitrous oxide, one of the main greenhouse gases. [18].

- The mangroves are a source of obtaining medicinal plants for the populations that inhabit them. [19]

All these aspects provide the rationale as to why community based mangrove management has been advocated by both academia and governing agencies and also re-emphasize [20]. the need for sustainably managing the mangrove forests, which are unfortunately disappearing rapidly worldwide [21]

The mangals in this Guinea-Bissau natural park include the following species: Rhizophora racemosa, Rhizophora mangle, Rhizophora harrisonii and Avicennia germinans (COR). Associated with this forest, we also find animal species such as the hippopotamus, Hippopotamus amphibius, Nile crocodile, Crocodylus niloticus and manatee, Trichechus sp. The park also provides shelter for a large number of birds [22].

As stated earlier, the park also includes other areas besides the mangals. A brief description is provided below:

- The palm forest area is made up of various species: Pterocarpus erinaceus, Dialium guineense, Khaya senegalensis, Parinari excelsa, Landolphia sp and Elaesis guineensis. Of these, the lastElaesis guineensis - is the most important, as its seeds produce a highly prized vegetable oil widely used in different industrial sectors [22]

- The savannah area constitutes the smallest association in the park. It is made up of gramineous plants from different genera,[23] most notably Panicum, Hypoltenio and Melinis. There is a scattering of acacias (Acacia arabica, Acacia senegal and Acacia catechu).

- The paddy fields area is the result of Portuguese colonization, it being the Portuguese colonists who introduced this crop[24]. In recent years, as this study confirms, these have expanded considerably due to the increase in population in the area of the natural park. 
This paper focuses on studying the changes in land use and evolution of vegetation in the Cacheu River Mangroves Natural Park between the years 2008 and 2015. The study is aimed at evaluating the sustainability of the natural park based on the above-mentioned changes over time.

\section{Materials and Methods}

To quantify the biomass in the Cacheu River Mangroves Natural Park, Guinea-Bissau, its current state and evolution over time, vegetation indices have been used [25]. This vegetation index are calculated from the digital image. Such images [26] processing of satellite data provides tools for analyzing the image through different algorithms and mathematical indices. [27].

A vegetation index is a parameter calculated based on the reflectance values of different wavelengths.[28] Its aim is to extract the information related to vegetation, minimizing the influence of disruptions such as those caused by soil and weather conditions [29] These indices are primarily used to distinguish plant cover from soil and to be able to evaluate some of the biophysical variables of the cover. [30] In this paper, the NDVI was used to see the variation in land use and changes in vegetation in the Cacheu River Mangroves Natural Park, Guinea-Bissau, with the purpose to evaluate its sustainability according to the current exploitation.

The NDVI is calculated based on the data corresponding to the red and near-infrared channels of the TERRA satellite by means of its ASTER sensor. [31] The data captured by all of these sensors are stored digitally in the form of tables and maps

The NDVI is an excellent indicator of plant health; a high value for this index means vigorous growth, while a low index indicates unhealthy plants. [19]

The use of quotients to distinguish vegetation masses is the result of the distinctive radiometric behavior of tree cover [32] The typical spectral signature of healthy vegetation shows a clear contrast between the visible bands, and especially the red band $(0.6-0.7 \mu \mathrm{m})$ and those included in the near-infrared band $(0.7-1.1 \mu \mathrm{m})$ [29]. Whereas in the visible region, the leaf pigments absorb most of the light they receive (to carry out photosynthesis), in the near-infrared these substances appear quite transparent. For this reason, healthy vegetation has low reflectance in the red band of the spectrum and high reflectance in the near-infrared band. The quotient used is expressed as follows:

$$
N D V I=\frac{I R p-R}{I R p+R}
$$

Where:

IRp: Near-infrared band

$R$ : Visible red band

Translating the results produced by the ASTER image, we get: 


$$
N D V I_{A S T E R}=\frac{A S 3-A S 2}{A S 3+A S 2}
$$

The contrast with unhealthy vegetation, and especially with the ground, is quite obvious in both bands. [33] The greater the contrast between the digital levels of the infrared and red band, the more healthy vegetation the cover studied will have. Low contrast values indicate unhealthy or senescent vegetation [29]

For the purpose of this study, the NDVI of the Cacheu River Mangroves Natural Park was calculated using the country's military maps, which are on the Universal Transverse Mercator coordinate system (UTM) and International ellipsoid. Central meridian $15^{\circ} \mathrm{W}$ of the Greenwich meridian. [34]. The distance between contour lines is 10 meters.

The sheets necessary to produce the mosaic map were those shown in Table 1 below:

Table 1: Map sheets used to create the mosaic of the park

\begin{tabular}{|c|c|c|c|c|c|}
\hline $\begin{array}{l}\text { VARELA } \\
\text { (February 1954) }\end{array}$ & $\begin{array}{l}\text { SUSANA } \\
\text { (Febuary 1953) }\end{array}$ & $\begin{array}{l}\text { S. Domingos } \\
\text { (February 1953) }\end{array}$ & $\begin{array}{l}\text { SEDENGAL } \\
\text { (February 1953) }\end{array}$ & $\begin{array}{l}\text { BIGENE } \\
\text { (February 1954) }\end{array}$ & $\begin{array}{l}\text { BINTA } \\
\text { (February 1954) }\end{array}$ \\
\hline & $\begin{array}{l}\text { JUFUNCO } \\
\text { (March 1951) }\end{array}$ & $\begin{array}{l}\text { T. PINTO } \\
\text { (February 1954) }\end{array}$ & $\begin{array}{l}\text { PELUNDO } \\
\text { (February 1954) }\end{array}$ & $\begin{array}{l}\text { BULA } \\
\text { (February 1954) }\end{array}$ & $\begin{array}{l}\text { MANSOA } \\
\text { (February 1954) }\end{array}$ \\
\hline & $\begin{array}{l}\text { I.DE JETA } \\
\text { (March 1951) }\end{array}$ & $\begin{array}{l}\text { CAIO } \\
\text { (March 1950) }\end{array}$ & $\begin{array}{l}\text { QUINHAMEL } \\
\text { (February 1948) }\end{array}$ & $\begin{array}{l}\text { BISDSAU } \\
\text { (February 1945) }\end{array}$ & $\begin{array}{l}\text { TITE } \\
\text { (February 1954) }\end{array}$ \\
\hline & & & & $\begin{array}{l}\text { BOLAMA } \\
\text { (May 1948) }\end{array}$ & $\begin{array}{l}\text { S.JOAO } \\
\text { (May 1945) }\end{array}$ \\
\hline
\end{tabular}

The ASTER images corresponding to the park and the period studied were also required. The image search was done using the ASTER-LANDSAT-USGS-Globalvis catalog [35]

The ASTER scenes were chosen based on the following selection criteria [36]. Cloud percentage: $0 \%$.

- Images covering the entire area of the park.

- Search period: January 2002-December 2017.

- Time of year: spring, as this is the period when the vegetation is in its optimum state.

The search range 2002-2017 was selected, as the TERRA satellite was put into orbit in December 1999. 2017 was established as the limit of the range because the study begun in the later part of that year. [37].

The first search was made using the following criteria:

- Date range: March 2000-November 2014 (January and February 2000 were omitted because this is considered the dry period and the status of vegetation is not optimal).

- Cloud percentage: $0 \%$. 
- Area of interest: an area around the park's vector plane was defined.

In order for the vegetation indices to be compared for all years for which we have ASTER images, the season [28] of the year when they were captured must coincide in order for the vegetation to always appear at the same phenological stage.[38]

As a result of this search using the criteria described above, just 21 scenes were obtained. The first ASTER scenes of the park that could be obtained were from July 2010, but they were discarded because they covered a very limited area of the park and the cloud percentage was very high. Expanding the search range to 2017 and discarding the two scenes from 2010, it was only possible to select five scenes of which just three were valid, given that they were from similar dates and also covered the entirety of Cacheu River Park.

Therefore, the main determining factor when selecting the year in which to begin the study and the time of year was the lack of available ASTER scenes for the park area during this period of time. This was primarily due to the sensor's limited storage and broadcast capacity. [39]

Once the appropriate material, country maps and ASTER images had been selected, work begun on calculating the NDVIs. The first step consisted of georeferencing the map sheets that make up the park, [40] based on the 1/50,000 scale country map sheets shown in Table 1. These were processed to create the mosaic of sheets used as a base to make up the park. The modus operandi is laid out below:

- Preparation of the map sheets

- Cutting the 1/ 50,000 sheets

- Geometric correction of the sheets

- Creation of the mosaic map from all the 1/50,000 sheets that make up the entire Cacheu River Park

Once the map sheets for the park had been georeferenced, a vector file was created based on the map downloaded from the global protected areas database. This was then digitized and georeferenced. 


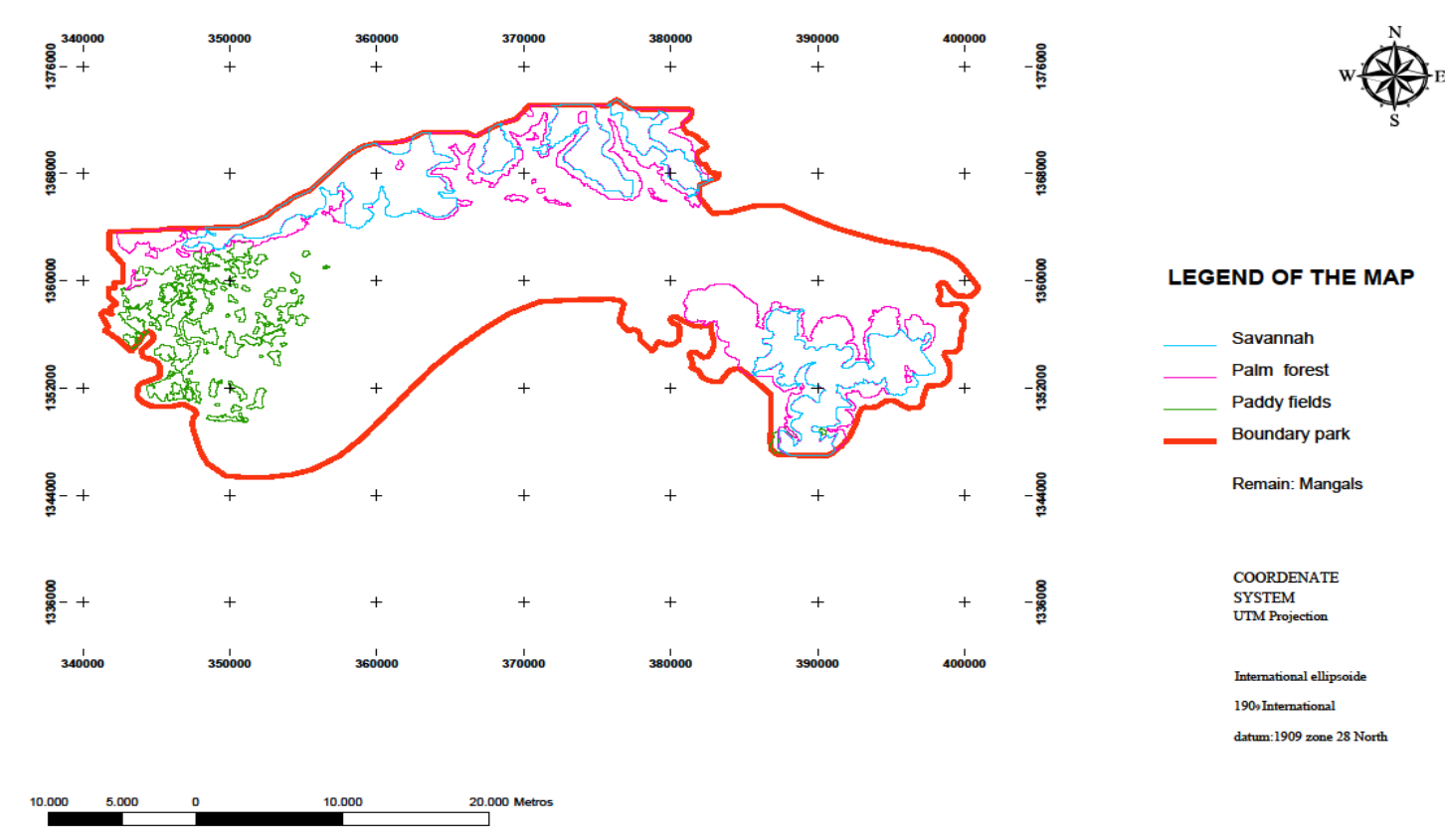

Figure 3: Digitalization map of the different areas of the park

The next step in obtaining the vegetation indices to be calculated involved processing the ASTER images from the TERRA satellite. This consisted of:

- Geometric correction of each of the images

- Atmospheric correction of the images

- Cutting each scene

- Calculating the NDVI for each ASTER scene

- Mosaic of ASTER scenes for 2010, 2017

- Mosaic of ASTER scenes with NDVI for 2010, 2017.

Having properly processed the ASTER images for the area under study in order to calculate the NDVIs, the ASTER mosaics were created for the years 2010 and 2017. To do this, ten plots were digitized for each class (except for the "savannahs," which represent a much smaller area than the other classes and for which only five were digitized) based on the legend on the 1/50,000 map of the area. Next, the statistics for each of the plots were calculated for each of the classes considered.

As mentioned earlier, [41] the algorithm used to calculate the NDVI is as follows:

$$
N D V I=\frac{I R p-R}{I R p+R}
$$

Where:

IRp: Near-infrared band

$\boldsymbol{R}$ : Visible red band 
Translating the results produced by the ASTER image, we get: [42]

$$
N D V I_{A S T E R}=\frac{A S 3-A S 2}{A S 3+A S 2}
$$

In order to concentrate the results in Cacheu River Natural Park, each mosaic was cut along the park vector. Next, the attributes of each resulting image were edited based on the criteria for designating categories and colors shown in Table 2.

Table 2: Designation of NDVI colors and categories

\begin{tabular}{|l|l|l|l|l|}
\hline Category & NVDI $[-1,1]$ & NVDI $[0,255]$ & Vegetable Cover & Color \\
\hline 0 & $<0$ & $<127$ & Null & \\
\hline 1 & $0-0.2$ & $128-153$ & Low & \\
\hline 2 & $0.2-0.4$ & $157-179$ & Middle-low & \\
\hline 3 & $0.4-0.6$ & $180-205$ & Middle & \\
\hline 4 & $0.6-0.8$ & $206-231$ & Middle-high & \\
\hline 5 & $0.8-1.0$ & $232-255$ & High & \\
\hline
\end{tabular}

\section{Results}

Two resulting images were obtained for each ASTER scene. One in decimal format, with NDVI values between -1 and 1 (Figures 3 to 5), [43] and another with non-editable attributes. The second resulting image is an image in integer format, with values between 0 and 255 and editable attributes. 


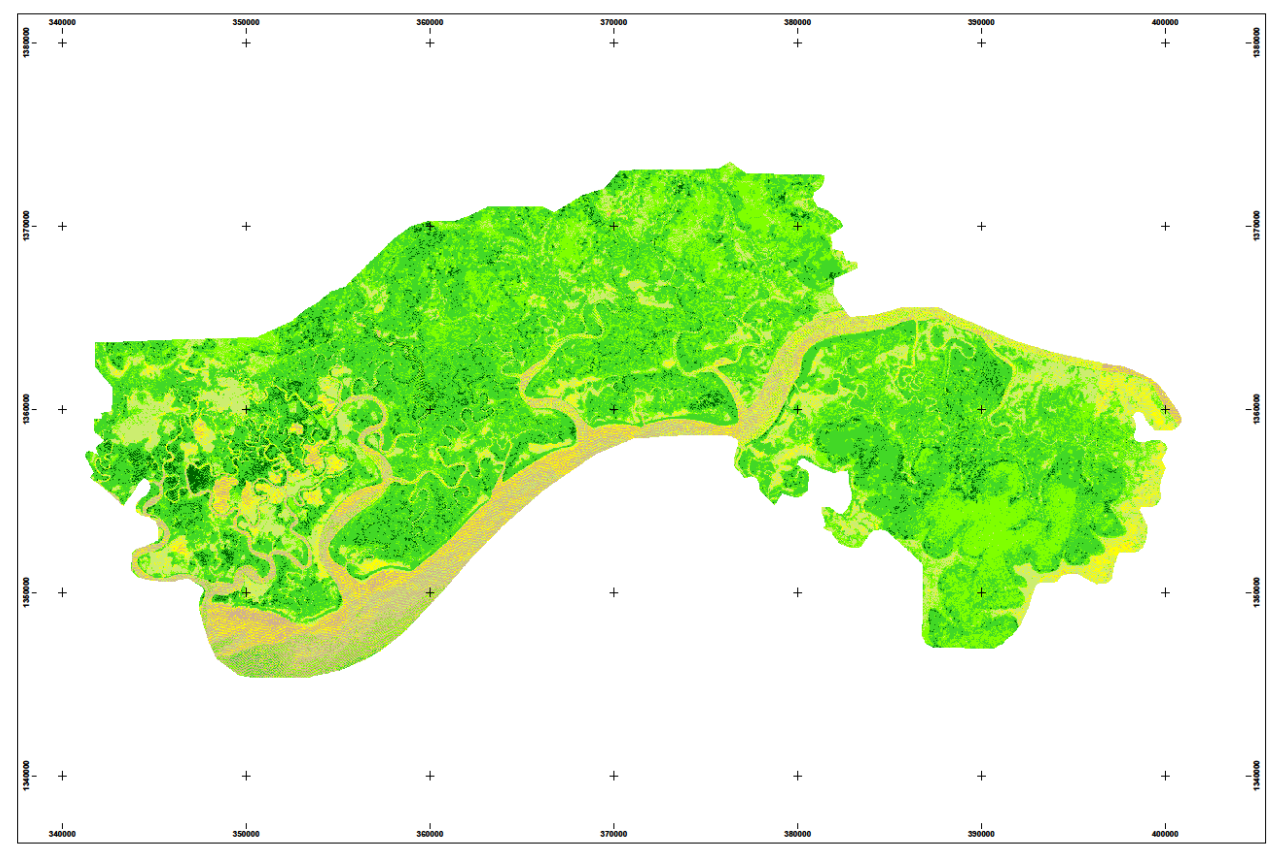

$\square^{20127}$

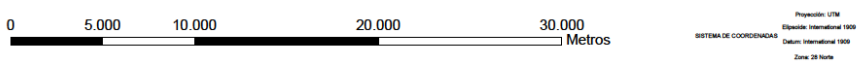

Figure 4: Mosaic with NVDI for the year 2010

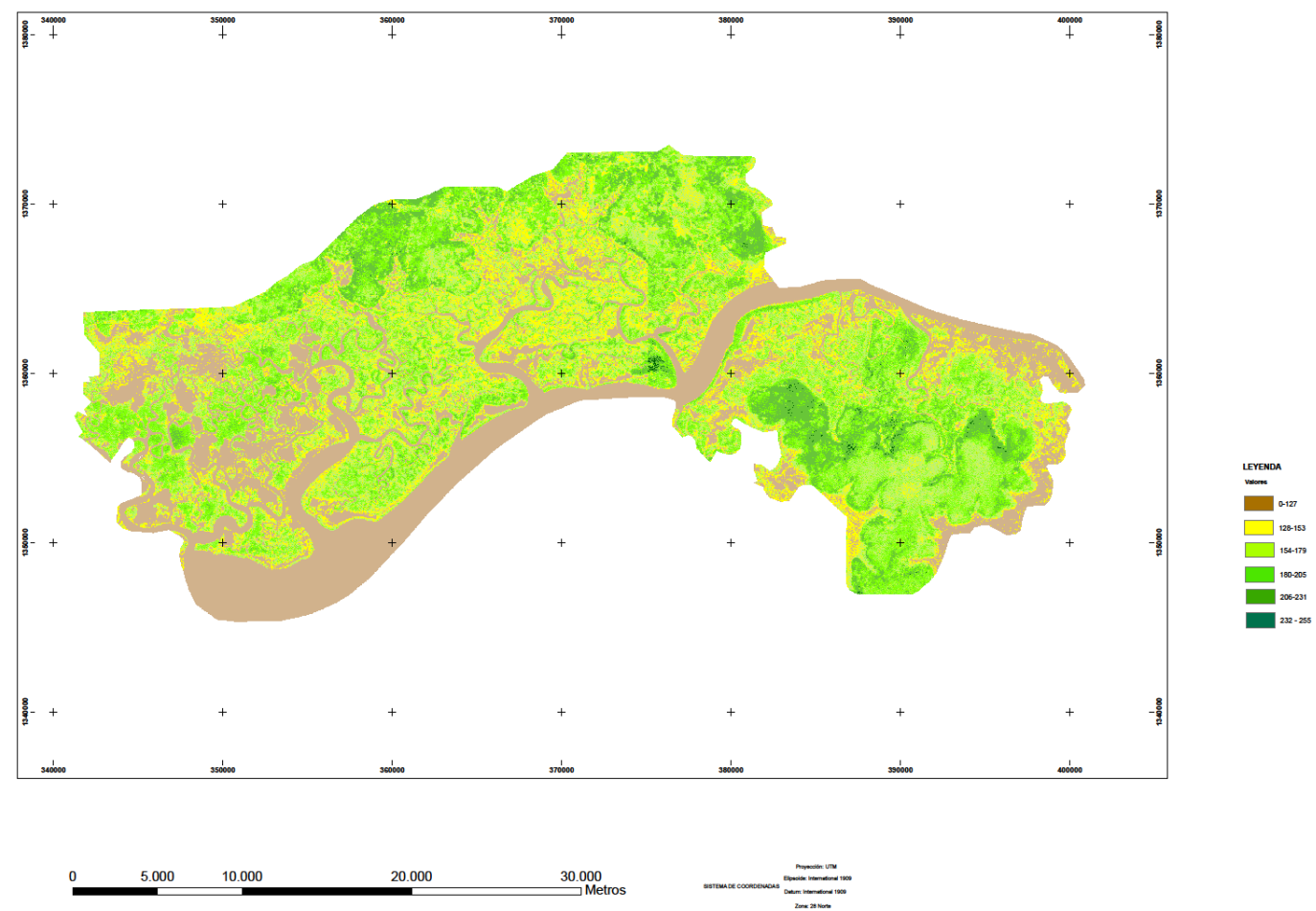

Figure 5: Mosaic with NVDI for the year 2017 
Comparing the colors in Table 2 with the different colored areas on the figures obtained by superimposing the ASTER images, we can see that the vegetation has undergone changes. To confirm this, the NDVI was calculated for each of the years considered and for each class. [44]

The results shown below were obtained from statistical calculations performed on the ASTER scene mosaics with NDVI for the years 2010 and 2017. The statistical variables analyzed were the maximum and minimum value, mean, median, mode and standard deviation of the vegetation index.

The statistical calculations were first applied to the entire area of the park, as shown in Table 3. This gave us an overview of what happened in the entire park over the course of the period studied. The calculations were then done for the areas in each class selected using stratified statistical sampling. These were also digitized in order to analyze their changes separately. The classes studied are those mentioned throughout this paper: mangals, paddy fields, palm forest, savannahs and others. For each one of these, the different NDVIs were calculated by year studied.

Table 3. NDVI statistical results for the entire park

\begin{tabular}{lllll}
\hline YEAR & MEAN & MEDIAN & MODE & STD \\
\hline 2008 & 192.907 & 195 & 171 & 26.764 \\
2015 & 151.470 & 153 & 137 & 30.579 \\
\hline
\end{tabular}

The overall NDVIs for the park for each year studied confirm what it was already possible to see in the ASTER images: the vegetation has undergone significant changes. The general trend observed is a decrease in the vegetation indices in each of the years studied.[18] This indicates that, generally, the areas covered by vegetation have decreased.

Through a detailed study of each vegetation area, we will show how much it has changed over time.

\subsection{Mangals}

Table 4. NDVI statistical results for the Mangals area

\begin{tabular}{lllllllll}
\hline & 2010 & & & & 2017 \\
Plot & Mean & Median & Mode & STD & Mean & Median & Mode & STD \\
\hline 1 & 213.001 & 214 & 213 & 14.261 & 160.000 & 163 & 169 & 24.554 \\
2 & 185.030 & 179 & 172 & 20.959 & 101.995 & 86 & 79 & 40.213 \\
3 & 216.003 & 215 & 213 & 8.781 & 170.542 & 171 & 169 & 16.389 \\
4 & 214.952 & 215 & 210 & 11.597 & 174.829 & 174 & 169 & 21.006 \\
5 & 209.199 & 211 & 210 & 18.708 & 173.635 & 174 & 169 & 31.858 \\
6 & 210.089 & 209 & 210 & 8.495 & 161.230 & 159 & 169 & 17.9 \\
7 & 210.110 & 213 & 213 & 17.173 & 164.841 & 166 & 169 & 26.832 \\
8 & 206.030 & 208 & 204 & 16.27 & 160.913 & 160 & 169 & 23.71 \\
9 & 191.952 & 198 & 204 & 21.663 & 156.634 & 161 & 169 & 27.16 \\
10 & 215.241 & 216 & 213 & 11.968 & 181.988 & 184 & 190 & 19.859 \\
\hline
\end{tabular}




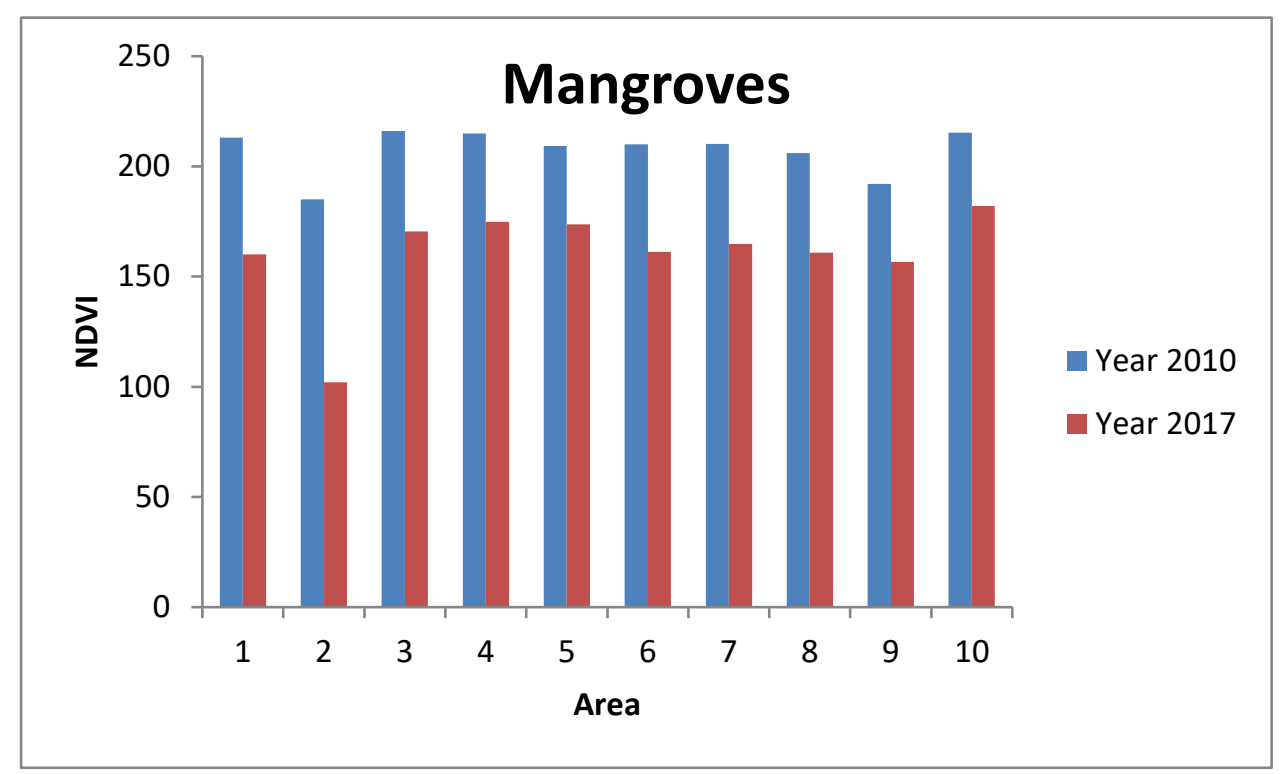

Figure 6: Change in NDVI for the mangal area

For all of the plots, a decrease in NDVI was observed in the mangal area between 2010 and 2017. This decline becomes more obvious between the years 2010 and 2017.

\subsection{Paddy Fields}

Table 5. NDVI statistical results for the paddy field area

\begin{tabular}{lllllllll}
\hline \multicolumn{2}{l}{2008} & & & & 2015 \\
Plot & Mean & Median & Mode & STD & Mean & Median & Mode & STD \\
\hline 1 & 169.964 & 110.178 & 164 & 22.897 & 169.964 & 107 & 108 & 29.742 \\
2 & 201.299 & 148.309 & 227 & 32.251 & 201.299 & 160 & 171 & 37.633 \\
3 & 198.201 & 150.009 & 218 & 32.497 & 198.201 & 162 & 169 & 43.61 \\
4 & 167.891 & 115.267 & 169 & 31.409 & 167.891 & 107 & 127 & 40.56 \\
5 & 184.236 & 123.112 & 170 & 26.138 & 184.236 & 117 & 108 & 31.1 \\
6 & 206.060 & 157.913 & 234 & 29.095 & 206.060 & 166 & 185 & 34.077 \\
7 & 186.072 & 135.760 & 170 & 25.6 & 186.072 & 122 & 118 & 31.083 \\
8 & 210.021 & 176.587 & 227 & 25.901 & 210.021 & 180 & 169 & 21.836 \\
9 & 202.925 & 152.541 & 228 & 32.235 & 202.925 & 169 & 171 & 36.013 \\
10 & 194.918 & 139.939 & 236 & 44.466 & 194.918 & 173 & 185 & 64.097 \\
\hline
\end{tabular}




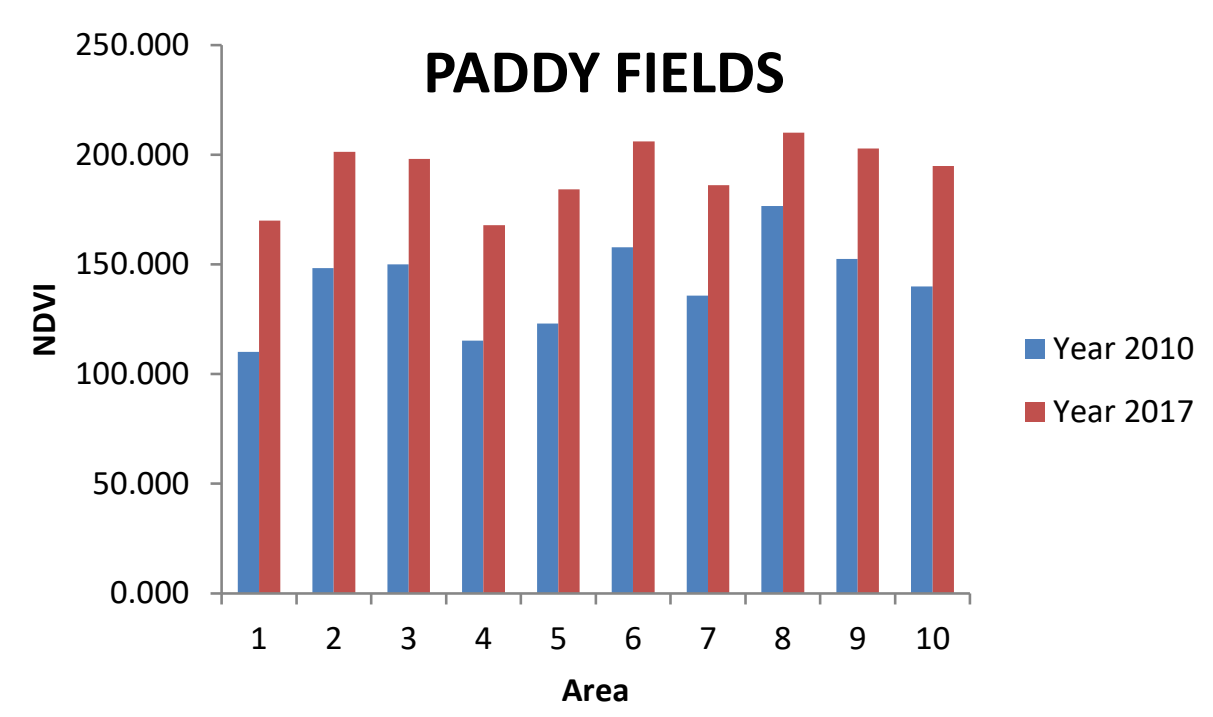

Figure 7: Change in NDVI for the paddy field area

As can be seen from the graphs above, the NDVI index has increased for paddy field class, which implies that the area occupied by rice plantations has increased over the period of time that has been studied.

\subsection{Palm forest}

Table 6. NDVI statistical results for the palm forest area

\begin{tabular}{lcccccccc}
\hline \multicolumn{2}{c}{2010} & & & \multicolumn{2}{c}{2017} \\
Plot & Mean & Median & Mode & STD & Mean & Median & Mode & STD \\
\hline 1 & 181.539 & 186 & 0 & 43.677 & 137.943 & 128 & 0 & 43.707 \\
2 & 164.555 & 160 & 153 & 17.843 & 115.845 & 114 & 115 & 12.567 \\
3 & 193.602 & 192 & 175 & 22.98 & 147.609 & 148 & 133 & 21.536 \\
4 & 185.979 & 189 & 0 & 40.432 & 142.759 & 142 & 128 & 36.225 \\
5 & 190.873 & 192 & 185 & 24.356 & 140.917 & 138 & 127 & 26.272 \\
6 & 189.138 & 191 & 152 & 31.912 & 144.69 & 143 & 111 & 27.622 \\
7 & 204.895 & 207 & 203 & 19.504 & 165.293 & 167 & 184 & 30.232 \\
8 & 204.669 & 209 & 221 & 19.83 & 180.882 & 195 & 213 & 36.578 \\
9 & 202.968 & 208 & 221 & 32.656 & 178.847 & 182 & 162 & 34.295 \\
10 & 209.864 & 211 & 203 & 16.081 & 189.876 & 191 & 182 & 22.157 \\
\hline
\end{tabular}




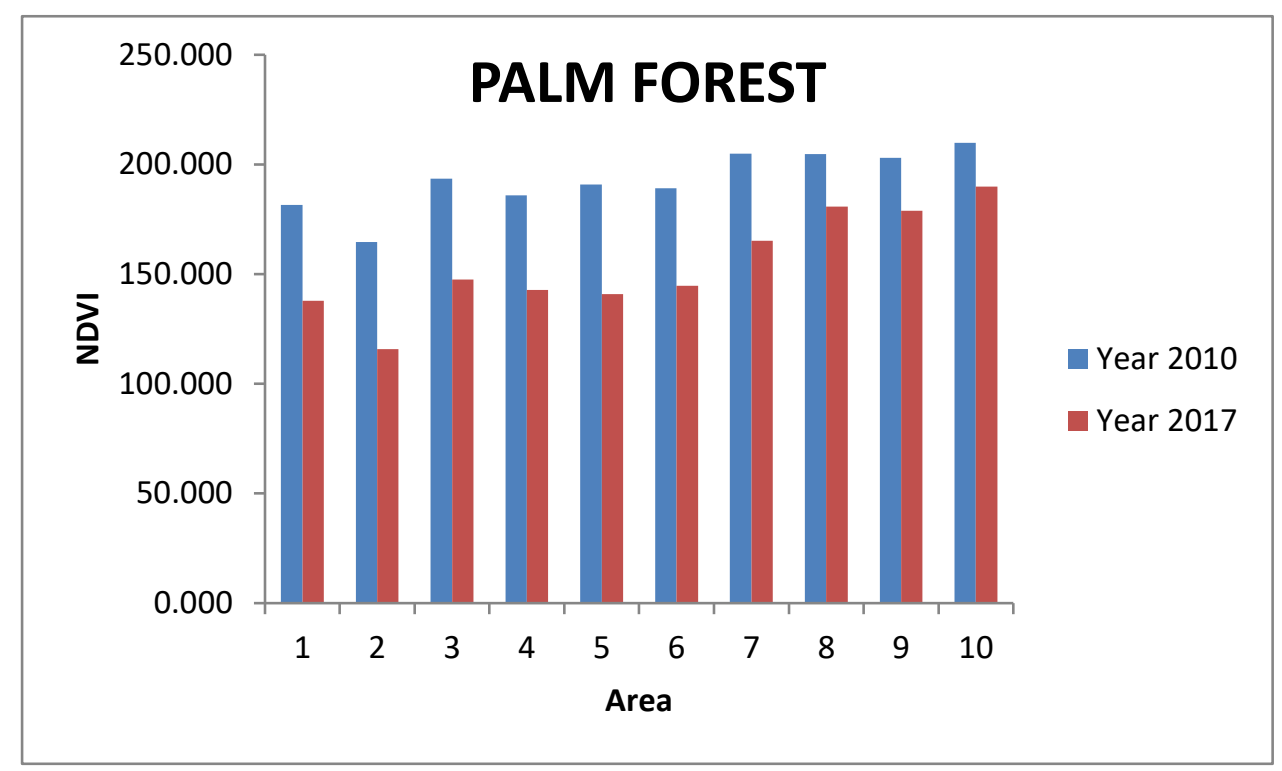

Figure 8: Change in NDVI for the palm forest area

As we can see in the tables and graphs, the palm forests also experienced changes, although to a lesser extent than the mangrove forests. The vegetation index decreased on all plots during the period studied.

\subsection{Savannahs}

Table 7. NDVI statistical results for the savannah area

\begin{tabular}{lllllllll}
\hline & 2010 & & & \multicolumn{2}{c}{2017} \\
Plot & Mean & Median & Mode & STD & Mean & Median & Mode & STD \\
\hline 1 & 187.879 & 204 & 0 & 59.486 & 161.015 & 175 & 0 & 57.174 \\
2 & 203.811 & 202 & 231 & 20.035 & 177.277 & 181 & 194 & 25.472 \\
3 & 180.001 & 197 & 0 & 62.194 & 161.988 & 178 & 0 & 58.424 \\
4 & 201.589 & 202 & 197 & 21.731 & 185.887 & 190 & 210 & 24.736 \\
5 & 202.719 & 207 & 203 & 31.075 & 184.125 & 187 & 185 & 31.965 \\
\hline
\end{tabular}




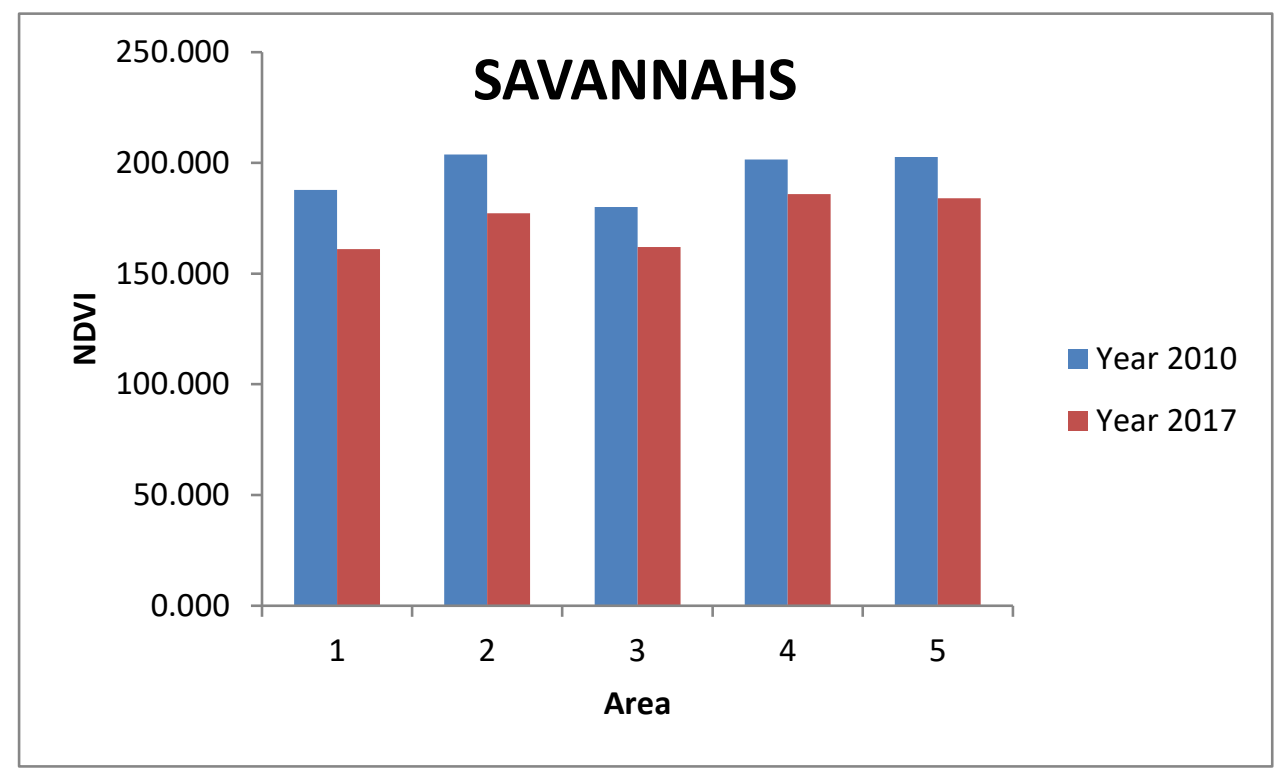

Figure 9: Change in NDVI for the savannah area

Of all the formations studied, the savannahs showed the least significant change. We can see that the NDVI decreased slightly between 2010 and 2017.

\subsection{Other areas}

Table 8. NDVI statistical results for Other areas.

\begin{tabular}{ccccccccc}
\hline \multicolumn{9}{c}{2010} \\
Plot & Mean & Med & Mod & STD & Mean & Med & Mod & STD \\
\hline 1 & 198.001 & 206 & 210 & 22.904 & 138.232 & 141 & 127 & 29.404 \\
2 & 174.002 & 168 & 160 & 23.094 & 120.754 & 116 & 127 & 24.455 \\
3 & 180.002 & 176 & 153 & 27.761 & 120.502 & 115 & 108 & 24.570 \\
4 & 192.330 & 199 & 210 & 21.652 & 138.950 & 141 & 127 & 23.948 \\
5 & 169.004 & 160 & 154 & 20.292 & 131.623 & 123 & 120 & 19.353 \\
6 & 171.549 & 169 & 170 & 17.043 & 133.269 & 130 & 127 & 20.556 \\
7 & 181.058 & 177 & 164 & 21.010 & 132.360 & 130 & 127 & 27.526 \\
8 & 168.093 & 161 & 154 & 19.932 & 115.000 & 112 & 107 & 14.581 \\
9 & 168.927 & 166 & 166 & 16.794 & 113.563 & 111 & 108 & 22.312 \\
10 & 169.124 & 162 & 150 & 19.498 & 111.125 & 111 & 115 & 13.799 \\
\hline
\end{tabular}




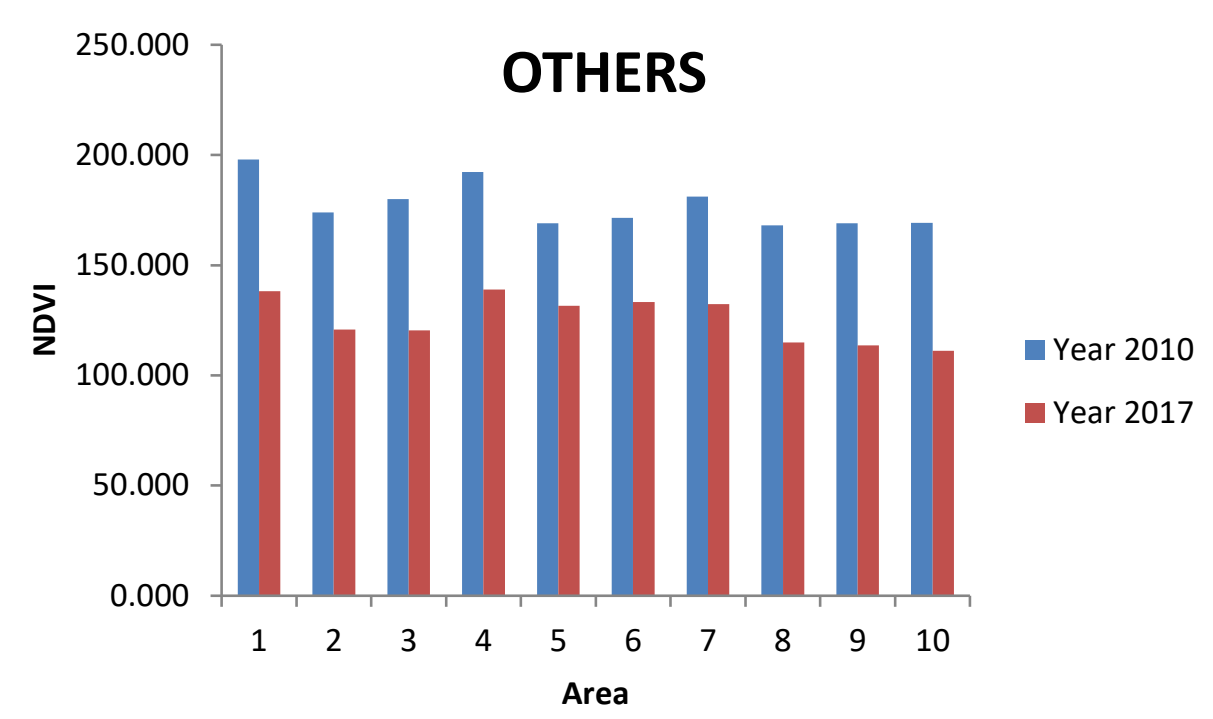

Figure 10: Change in NDVI for others

The analysis of the areas called "Other" (occupied by villages and human settlements) leads to the conclusion that it is these areas of the park the ones that have suffered the greatest degradation. This degradation is related to the increase in population, which as on the rest of the African continent, is much higher in the vicinity of rivers and along the coast than in inland areas (e.g., almost $80 \%$ of Guinea-Bissau's population resides in the coastal zone [17] This fact has a very relevant impact on the degradation of the mangrove swamps due to land reclamation by the increasing population, pointing precisely this fact as the principal cause of the disappearance of mangals in the area.

As a summary, table 9, is presented with the NDVI average for each of the classes studied

Table 9: NDVI Average for class

\begin{tabular}{lll}
\hline Class & 2010 & 2017 \\
\hline Manglares & 207,161 & 160,161 \\
Palm forest & 192,808 & 154,466 \\
Paddy fields & 140,962 & 192,159 \\
Savannah & 195,2 & 174,058 \\
others & 177,209 & 125,538 \\
\hline
\end{tabular}




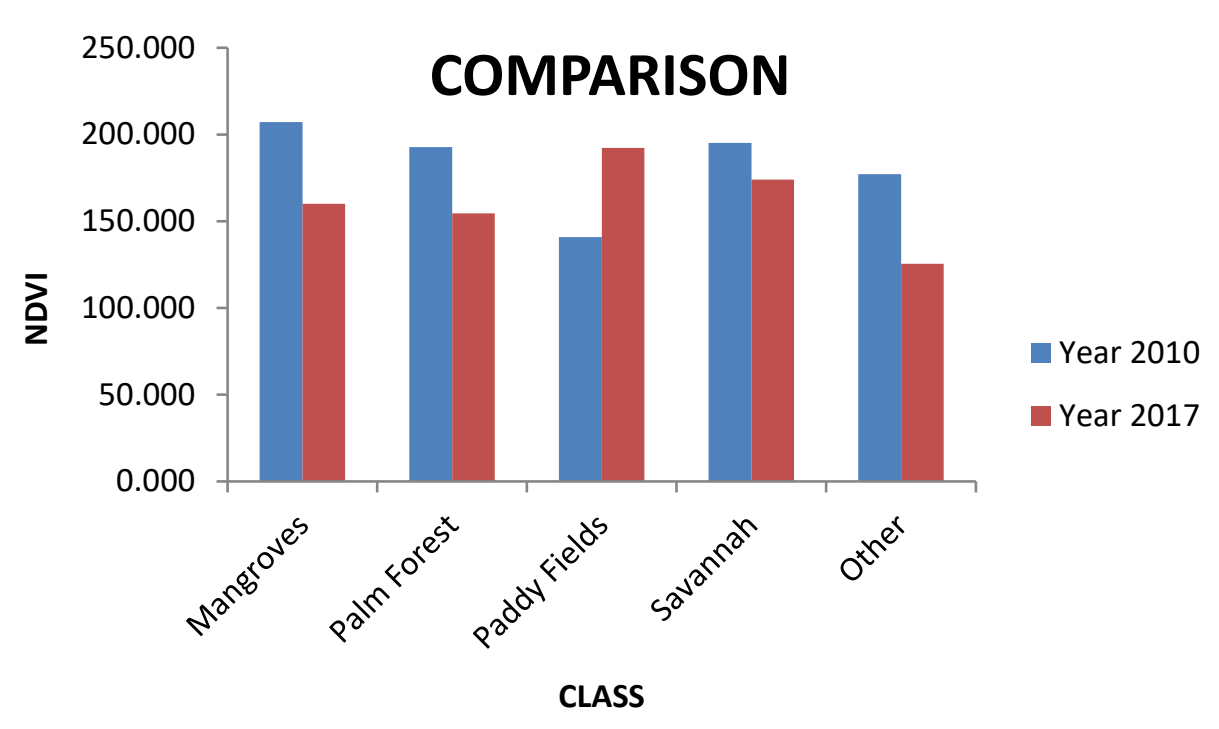

Figure 11: Comparison between NDVI for different classes

As can be seen in the Figure 11, the class that has a lower NDVI index is what we have called others, which includes the populations and human settlements collected within the park. A decrease in the NDVI indices can be observed for all the classes studied except for the paddies. This means that in general the areas covered with vegetation of the park have been suffering an important loss of vegetation, which implies a degradation of the Natural Park.

\section{Conclusions}

- By using remote sensing techniques such as vegetation indices calculated based on ASTER scenes and basemaps of Guinea-Bissau, it has been demonstrated that Cacheu River Mangroves Natural Park is undergoing changes in land use and vegetation.

- These changes in land use have had an effect on the degradation of the plant cover in one of the most important protected areas of Guinea-Bissau, containing one of the most significant mangrove formations in West Africa.

- The analysis of the different areas studied between the years 2010 and 2017 indicates that the biggest changes occurred in the mangrove swamps, specifically the areas closest to population settlements. This gradual destruction of the mangals is directly related to the change in land use in these areas, which shifted from mangrove forests to population centers and paddy fields, that are later abandoned and become non-vegetated areas. This is in addition to overexploitation of the wood-yielding mangrove species.

- The area of palm forests also decreased slightly, although less than the other areas studied. The reason for the better maintenance of these areas is based on economic principles and related to the production of cashew nuts associated with these palms, which constitutes one of the main agricultural products for export. 
- The villages show the greatest degradation of all those studied. This is due to the increase in population the country experienced during the years studied, which as in the majority of African countries, is settled along river banks and the coast. These settlements have a particular impact on the degradation of the mangrove swamps and their replacement by paddy fields.

In view of the changes identified, it is clear that the natural park is not well managed. The following measures are proposed to improve sustainability of the park:

- Drawing up a rational land use plan, respecting traditional uses and placing special emphasis on the mangrove swamps.

- Reforestation of the most degraded mangrove swamps.

- Conducting education and awareness-raising campaigns to inform the population of the importance of conserving these protected areas, especially the mangrove swamps, for their future.

- Implementing a system for ongoing monitoring and control of the forest areas to ensure their optimum growth and maintenance.

Author Contributions: Maria Isabel Más-López and Eva M. García del Toro participated in all phases and contributed equally to this work

Acknowledgments: This work was supported by ETS Ingeniería Civil de la Universidad Politécnica de Madrid.

Conflicts of Interest: The authors declare no conflict of interest.

\section{References}

[1] Achard F, Eva HD, Stibig H, Mayaux P, Gallego J, Richards T, et al. Determination of The World's Humid Tropical Deforestation Rates during the 1990's. 2002.

[2] FAO. Global Forest Resource Assessment 2005. FAO For Pap 2005;147:129-47.

[3] Carey AB, Lippke BR, Sessoins J. Intentional SystemsManagement: Managing Forests for Biodiversity. J Sustain For 1999;9:83-125. doi:10.1300/J091v09n03_05.

[4] Malhi Y, Adu-bredu S, Asare RA, Lewis SL, Mayaux P. African rainforests : past, present and future 2013.

[5] Mayaux P, Pekel JF, Desclée B, Donnay F, Lupi A, Achard F, et al. State and evolution of the African rainforests between 1990 and 2010. Philos Trans R Soc B Biol Sci 2013;368. doi:10.1098/rstb.2012.0300.

[6] Struhsaker TT, Struhsaker PJ, Siex KS. Conserving Africa's rain forests: Problems in protected areas and possible solutions. Biol Conserv 2005;123:45-54. doi:10.1016/j.biocon.2004.10.007.

[7] Harrison, Steve; Suh J. Progress and prospects of community forestry in developing and developed countries. Small-Scale For Econ Manag Policy 2004;3:287-302. doi:10.1007/s11842-004-0021-2.

[8] Adeel Z, Pomeroy R. Assessment and management of mangrove ecosystems in developing countries. 
Trees - Struct Funct 2002;16:235-8. doi:10.1007/s00468-002-0168-4.

[9] Kathiresan K, Bingham BL. Biology of mangroves and mangrove Ecosystems. Adv Mar Biol 2001;40:81-251. doi:10.1016/S0065-2881(01)40003-4.

[10] Baran E. A review of quantified relationships between mangroves and coastal resources. Phuket Mar Biol Cent Res Bull 1999;62:57-64. doi:10.1007/s10973-014-3667-9.

[11] ONG KERTJ. Different kinds of mangrove forests provide different goods and services. Lobal Ecol \&amp;Amp; Biogeogr Lett 2008;7:83-94.

[12] Badola R, Hussain SA. Valuing ecosystem functions: An empirical study on the storm protection function of Bhitarkanika mangrove ecosystem, India. Environ Conserv 2005;32:85-92. doi:10.1017/S0376892905001967.

[13] Kathiresan K, Rajendran N. Coastal mangrove forests mitigated tsunami. Estuar Coast Shelf Sci 2005;65:601-6. doi:10.1016/j.ecss.2005.06.022.

[14] Tri NH, Adger WN, Kelly PM. Natural resource management in mitigating climate impacts: The example of mangrove restoration in Vietnam. Glob Environ Chang 1998;8:49-61. doi:10.1016/S09593780(97)00023-X.

[15] Hussain SA, Badola R. Valuing mangrove ecosystem services: Linking nutrient retention function of mangrove forests to enhanced agroecosystem production. Wetl Ecol Manag 2008;16:441-50. doi:10.1007/s11273-008-9080-z.

[16] Rasolofo M V. Use of mangroves by traditional fishermen in Madagascar. Mangroves Salt Marshes 1997;1:243-53. doi:10.1023/A:1009923022474.

[17] Andreetta A, Huertas AD, Lotti M, Cerise S. Land use changes affecting soil organic carbon storage along a mangrove swamp rice chronosequence in the Cacheu and Oio regions (northern GuineaBissau). Agric Ecosyst Environ 2016;216:314-21. doi:10.1016/j.agee.2015.10.017.

[18] Achard F, Beuchle R, Mayaux P, Stibig HJ, Bodart C, Brink A, et al. Determination of tropical deforestation rates and related carbon losses from 1990 to 2010. Glob Chang Biol 2014;20:2540-54. doi:10.1111/gcb.12605.

[19] Sampath KP, Bhowmik D, Duraivel S, Umadevi M. Traditional and Medicinal Uses of Banana. J Pharmacogn Phytochem 2012;1:51-63. doi:10.1023/A:1009988607044.

[20] Abuodha PAW, Kairo JG. Human-induced stresses on mangrove swamps along the Kenyan coast. Hydrobiologia 2001;458:255-65. doi:10.1023/A:1013130916811.

[21] Datta D, Chattopadhyay RN, Guha P. Community based mangrove management: A review on status and sustainability. J Environ Manage 2012;107:84-95. doi:10.1016/j.jenvman.2012.04.013.

[22] Luther DA, Greenberg R. Mangroves: A Global Perspective on the Evolution and Conservation of Their Terrestrial Vertebrates. Bioscience 2009;59:602-12. doi:10.1525/bio.2009.59.7.11.

[23] Baudena M, Dekker SC, Van Bodegom PM, Cuesta B, Higgins SI, Lehsten V, et al. Forests, savannas, and grasslands: Bridging the knowledge gap between ecology and Dynamic Global Vegetation Models. Biogeosciences 2015;12:1833-48. doi:10.5194/bg-12-1833-2015.

[24] Kormawa P, Touré AA. Rice Policy and Food Security in sub-Saharan Africa Editors : 2005.

[25] G. Gutman, Raymond A. Byrnes, J. Masek, S. Covington, C. Justice, S. Franks and RH. Towards monitoring land-cover and land-use changes at a global scale: the global land survey 2005. Photogramm Eng Remote Sensing 2008;74:6-10.

[26] Gandhi GM, Parthiban S, Thummalu N, Christy A. Ndvi: Vegetation Change Detection Using Remote Sensing and Gis - A Case Study of Vellore District. Procedia Comput Sci 2015;57:1199-210. doi:10.1016/j.procs.2015.07.415. 
[27] Cohen WB, Yang Z, Kennedy R. Detecting trends in forest disturbance and recovery using yearly Landsat time series: 2. TimeSync - Tools for calibration and validation. Remote Sens Environ 2010;114:2911-24. doi:10.1016/j.rse.2010.07.010.

[28] Li P, Jiang L, Feng Z. Cross-comparison of vegetation indices derived from landsat-7 enhanced thematic mapper plus (ETM+) and landsat-8 operational land imager (OLI) sensors. Remote Sens 2013;6:310-29. doi:10.3390/rs6010310.

[29] Peña-Barragán JM, Ngugi MK, Plant RE, Six J. Object-based crop identification using multiple vegetation indices, textural features and crop phenology. Remote Sens Environ 2011;115:1301-16. doi:10.1016/j.rse.2011.01.009.

[30] Cutler MEJ, Boyd DS, Foody GM, Vetrivel A. Estimating tropical forest biomass with a combination of SAR image texture and Landsat TM data: An assessment of predictions between regions. ISPRS J Photogramm Remote Sens 2012;70:66-77. doi:10.1016/j.isprsjprs.2012.03.011.

[31] Dube T, Mutanga O. Evaluating the utility of the medium-spatial resolution Landsat 8 multispectral sensor in quantifying aboveground biomass in uMgeni catchment, South Africa. ISPRS J Photogramm Remote Sens 2015;101:36-46. doi:10.1016/j.isprsjprs.2014.11.001.

[32] Morawitz DF, Blewett TM, Cohen A, Alberti M. Using NDVI to assess vegetative land cover change in Central Puget Sound. Environ Monit Assess 2006;114:85-106. doi:10.1007/s10661-006-1679-z.

[33] Hansen MC, Loveland TR. A review of large area monitoring of land cover change using Landsat data. Remote Sens Environ 2012;122:66-74. doi:10.1016/j.rse.2011.08.024.

[34] Dashtekian ES. Analysis of land use-land covers changes using normalized difference vegetation index (NDVI) differencing and classification methods. African J Agric Res 2013;8:4614-22.

[35] Principles G. JCSS Probibilistic Model Code 2001.

[36] John David Armston, Robert J. Denham, Tim J. Danaher, Peter F. Scarth TNM. Prediction and validation of foliage projective cover from Landsat-5 TM and Landsat-7 ETM+ imagery. J Appl Remote Sens 2009;31.

[37] Nemani R, Votava P, Michaelis A, Melton F, Milesi C. Collaborative supercomputing for global change science. Eos (Washington DC) 2011;92:109-10. doi:10.1029/2011EO130001.

[38] P. S. Roy SAR. Biomass estimation using satellite remote sensing data - An investigation on possible approaches for natural forest. J Biosci 1996;21:535-61.

[39] Schaaf CB, Gao F, Strahler AH, Lucht W, Li X, Tsang T, et al. First operational BRDF, albedo nadir reflectance products from MODIS. Remote Sens Environ 2002;83:135-48. doi:10.1016/S00344257(02)00091-3.

[40] Zuur AF, Ieno EN, Elphick CS. A protocol for data exploration to avoid common statistical problems. Methods Ecol Evol 2010;1:3-14. doi:10.1111/j.2041-210X.2009.00001.x.

[41] Townshend J.R.G. and Justice C.O. Selecting the spatial resolution of satellite sensors required for global monitoring of land transformations. J Remote Sens 1988;9:187-236.

[42] Ganguly S, Nemani RR, Zhang G, Hashimoto H, Milesi C, Michaelis A, et al. Generating global Leaf Area Index from Landsat: Algorithm formulation and demonstration. Remote Sens Environ 2012;122:185-202. doi:10.1016/j.rse.2011.10.032.

[43] Helder GC rBrian LML. Summary of current radiometric calibration coefficients for Landsat MSS, TM, ETM+, and EO-1 ALI sensors. Remote Sens Environ 2009;113:893-903.

[44] Butson CR, Fernandes RA. A consistency analysis of surface reflectance and leaf area index retrieval from overlapping clear-sky Landsat ETM+ imagery. Remote Sens Environ 2004;89:369-80. 


\section{Appendix B}

All appendix sections must be cited in the main text. In the appendixes, Figures, Tables, etc. should be labeled starting with 'A', e.g., Figure A1, Figure A2, etc.

\section{References}

References must be numbered in order of appearance in the text (including citations in tables and legends) and listed individually at the end of the manuscript. We recommend preparing the references with a bibliography software package, such as EndNote, ReferenceManager or Zotero to avoid typing mistakes and duplicated references. Include the digital object identifier (DOI) for all references where available.

Citations and References in Supplementary files are permitted provided that they also appear in the reference list here.

In the text, reference numbers should be placed in square brackets [ ], and placed before the punctuation; for example [1], [1-3] or [1,3]. For embedded citations in the text with pagination, use both parentheses and brackets to indicate the reference number and page numbers; for example [5] (p. 10), or [6] (pp. 101-105).

1. Author 1, A.B.; Author 2, C.D. Title of the article. Abbreviated Journal Name Year, Volume, page range.

2. Author 1, A.; Author 2, B. Title of the chapter. In Book Title, 2nd ed.; Editor 1, A., Editor 2, B., Eds.; Publisher: Publisher Location, Country, 2007; Volume 3, pp. 154-196.

3. Author 1, A.; Author 2, B. Book Title, 3rd ed.; Publisher: Publisher Location, Country, 2008; pp. 154-196.

4. Author 1, A.B.; Author 2, C. Title of Unpublished Work. Abbreviated Journal Name stage of publication (under review; accepted; in press).

5. Author 1, A.B. (University, City, State, Country); Author 2, C. (Institute, City, State, Country). Personal communication, 2012.

6. Author 1, A.B.; Author 2, C.D.; Author 3, E.F. Title of Presentation. In Title of the Collected Work (if available), Proceedings of the Name of the Conference, Location of Conference, Country, Date of Conference; Editor 1, Editor 2, Eds. (if available); Publisher: City, Country, Year (if available); Abstract Number (optional), Pagination (optional).

7. Author 1, A.B. Title of Thesis. Level of Thesis, Degree-Granting University, Location of University, Date of Completion.

8. Title of Site. Available online: URL (accessed on Day Month Year). 